\title{
LANNEA ACIDA: A REVIEW OF ITS MEDICINAL USES AND PHYTOCHEMISTRY AND PHARMACOLOGICAL PROPERTIES
}

\author{
ALFRED MAROYI* \\ Medicinal Plants and Economic Development (MPED) Research Centre, Department of Botany, University of Fort Hare, Private Bag X1314, \\ Alice 5700, South Africa. Email: amaroyi@ufh.ac.za
}

Received: 03 August 2018, Revised and Accepted: 01 September 2018

\begin{abstract}
Lannea acida is widely used as herbal medicine in West Africa. The present study critically reviewed the medicinal uses and phytochemistry and pharmacological properties of L. acida. The keywords including L. acida, its synonyms, English common names, medicinal uses, and phytochemistry and pharmacological properties of the species were searched using electronic databases such as ISI web of knowledge, ProQuest, ScienceDirect, OATD, Scopus, OpenThesis, PubMed, and Google Scholar. The search for pre-electronic literature such as conference papers, scientific articles, books, book chapters, dissertations, and theses was carried out at the university library. Literature studies revealed that L. acida is mainly used for injuries, inflammation and pain, gastrointestinal problems, fever and malaria, gynecological and pregnancy disorders, ethnoveterinary medicine, hemorrhoids, skin diseases, and infections. Phytochemical compounds identified from the species include alkaloids, cardiac glycosides, flavonoids, phenols, saponins, steroids, tannins, and terpenoids. Pharmacological studies revealed that $L$. acida extracts have anthelmintic, antibacterial, antidiarrheal, anti-inflammatory, antimycobacterial, antioxidant, estrogenic, fertility, hyaluronidase, phospholipase $\mathrm{A}_{2}$, proteolytic, and vibriocidal activities. Given the importance of L. acida as herbal medicine, there is a need for detailed studies aimed at establishing the efficacy, clinical relevance, and safety of the plant extracts and compounds.
\end{abstract}

Keywords: Anacardiaceae, Lannea acida, Traditional medicine, West Africa.

(C) 2018 The Authors. Published by Innovare Academic Sciences Pvt Ltd. This is an open access article under the CC BY license (http://creativecommons. org/licenses/by/4. 0/) DOI: http://dx.doi.org/10.22159/ajpcr.2018.v11i11.28813

\section{INTRODUCTION}

Lannea acida A. Rich. belongs to the cashew or Anacardiaceae family. The name of the genus, "Lannea," is based on a Latin word "lana" which translates to "wool" in reference to young plant parts which are densely hairy or possibly to the wool on the roots of some Lannea species [1,2]. The synonyms of L. acida are Lannea buettneri Engl., Lannea djalonica A. Chev., Lannea glaucescens Engl., Lannea lagdoensis (Engl. and K. Krause) Mildbr., Lannea oleosa A. Chev., Odinaacida (A. Chev.) Walp., and Sorindeia lagdoensis Engl. and K. Krause [3-6]. The genus Lannea consists of approximately 40 species which are usually trees, shrubs, or suffrutices, occupying different habitats in Sub-Saharan Africa, with only one species recorded in Tropical Asia and several species introduced throughout the world [4-6]. L. acida is a multipurpose tree indigenous to Benin, Burkina Faso, Cameroon, Central African Republic, Côte d'Ivoire, Gambia, Ghana, Guinea, Mali, Niger, and Nigeria [3,7-13]. The species has been recorded in wooded savannah, forest edges, bushed grassland, rocky outcrops, and near Riverson sandy soils at an altitude ranging from 0 to $1600 \mathrm{~m}$ above sea level [13]. The tree species is widely used by local communities in West Africa as a source of dye, food, medicines, and other commodities. Its berry-like fruits which are about $1 \mathrm{~cm}$ across and $1.5 \mathrm{~cm}$ long occur in large clusters and are consumed either fresh or dried and can be stored for use months later [14]. The fruits have a slightly acidic and somewhat resinous, pleasant taste, and both fresh and dried fruits are eaten raw or made into juice, jam, and puddings [14]. The young leaves of L. acida are cooked as leafy vegetables [13]. In clearing land for agricultural purposes, some communities in West Africa do not cut L. acida, thereby ensuring a continued supply of goods and ecosystem services provided by the species [13]. In Senegal, $L$. acida is regarded as an important herbal medicine, with different plant parts sold on informal herbal medicine markets [13]. Marquet and Jansen [15] identified L. acida as an important useful plant species with domestication potential in West Africa based on its multipurpose uses and popularity as herbal medicine. It is within this context that this review was undertaken aimed to summarize the medicinal uses and phytochemical and pharmacological properties of L. acida so as to provide baseline data required for evaluating the therapeutic potential of the species.

\section{MEDICINAL USES OF L. ACIDA}

The major documented diseases and ailments treated by L. acida extracts were grouped and classified following the guidelines provided by Cook [16] and Gruca et al. [17] (Table 1). The major medicinal uses of L. acida (in descending order of importance) include injuries, inflammation and pain, gastrointestinal problems, fever and malaria, gynecological and pregnancy disorders, ethnoveterinary medicine, haemorrhoids, skin diseases, and infections (Fig. 1). In multitherapeutic applications, the bark of L. acida is applied topically for swellings mixed with cloves of Parkia biglobosa (Jacq.) R. Br. ex G. Don, while the leaves of L. acida are mixed with leaves and roots of Alafia barteri Oliv. and Flueggea virosa (Roxb. ex Willd.) Royle and pods of Xylopia aethiopica (Dunal) A. Rich. as herbal medicine for cancer [18]. In Ghana, the leaves of L. acida are mixed with those of Azadirachta indica A. Juss. and Mangifera indica L. as herbal medicine for malaria [19]. The bark of L. acida is mixed with that of Guiera senegalensis J. F. Gmel as herbal medicine for intestinal parasites [20], while bark mixed with different plant parts of Euphorbia unispina N. E. Br. are used against new castle disease [21]. In Benin, the roots of L. acida are mixed with the bark of Detarium microcarpum Guill. and Perr. and Khaya senegalensis (Desv.) A. Juss. and used as ethnoveterinary medicine against foot and mouth [21].

\section{PHYTOCHEMISTRY AND PHARMACOLOGICAL PROPERTIES OF L. ACIDA}

Sultana and Ilyas [51] identified a flavanone, 6,7-(2",2"-dimethyl chromeno)-8- $\gamma, \gamma$-dimethyl allyl flavanone1 (Fig. 2) from the acetone extract of $L$. acida leaves using nuclear magnetic resonance (NMR) and ultraviolet-visible spectroscopy. Similarly, Muhaisen [52] identified four flavonoids which included 6,7-(2",2"-dimethyl chromeno)-8- $\gamma, \gamma$-dimethyl allyl flavanone 1 , 
Table 1: Medicinal uses of Lannea acida

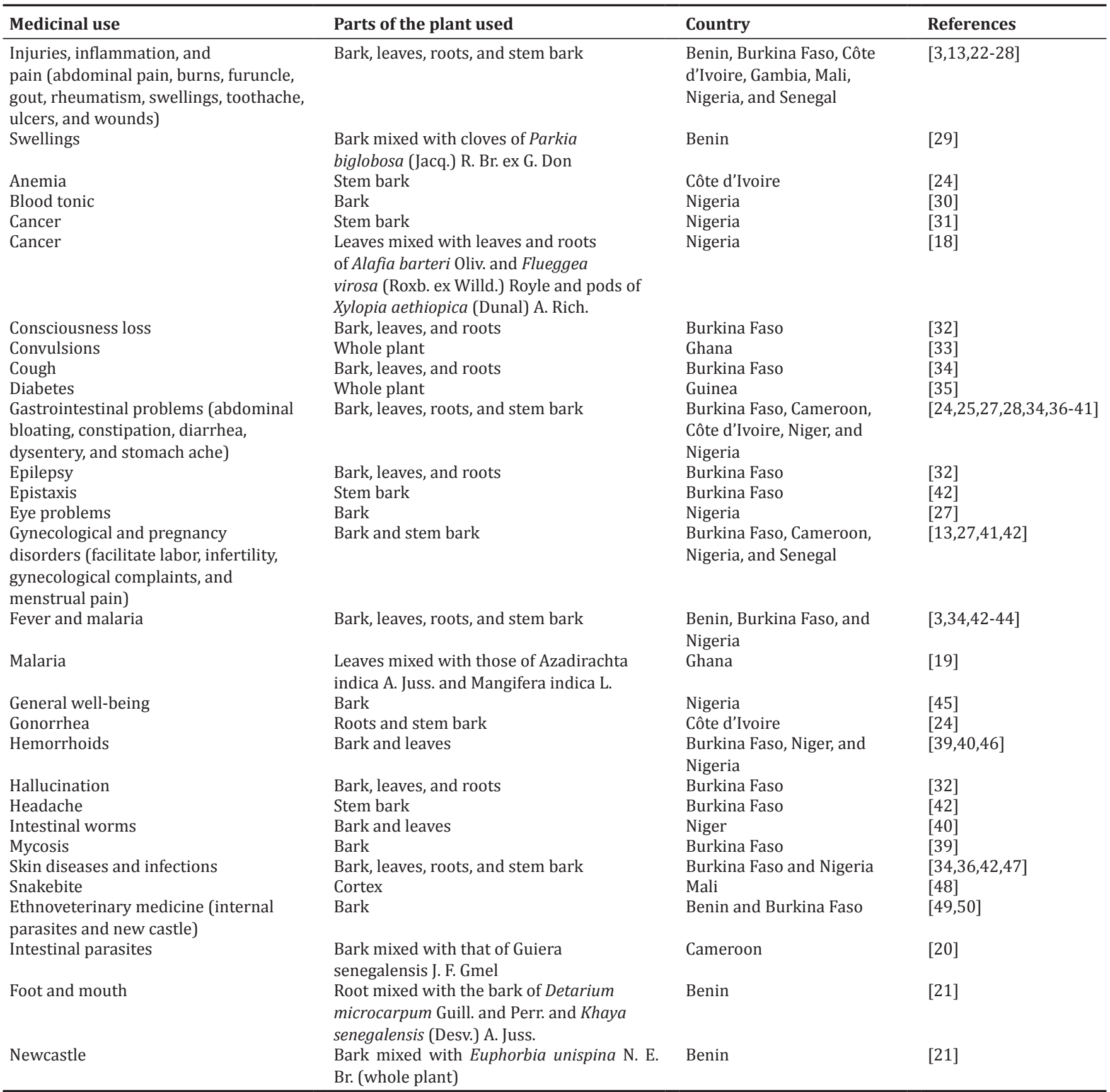

3',4'dihydroxy-7,8 (2",2"dimethyl chromeno)-6 $6, \gamma$-dimethyl allyl flavonol 2, 7-methyltectorigenin 3, and irisolidone 4 (Fig. 2) from the bark of L. acida using NMR, UV, infrared, and mass spectrometry. Flavonoids are characterized by several pharmacological properties, for example, irisolidone 4 is known to possess anti-Helicobacter pylori activities [53], inhibition of prostaglandin E2 production [54], hepatoprotective activities [55,56], cancer chemopreventive activities [57], estrogenic activities [58], inhibitory effect of JC1 virus gene expression [59], anti-inflammatory activities [60,61], and protective properties against hydrogen peroxide $\left(\mathrm{H}_{2} \mathrm{O}_{2}\right)$ [62]. Other phytochemical compounds identified from the bark and stem bark of $L$. acida include alkaloids, cardiac glycosides, phenols, saponins, steroids, tannins, and terpenoids [37,41,63-65]. Leung et al. [66] analyzed the calcium, carbohydrates, energy, fat, fiber, phosphorous, and protein content of L. acida leaves as a means of estimating the quality of leaves as vegetable sources (Table 2).
The pharmacological activities exhibited by $L$. acida extracts include the following: Anthelmintic [25], antibacterial [24,67], antidiarrheal [37], anti-inflammatory [64], antimycobacterial [34], antioxidant [65,67], estrogenic [41], fertility [68], hyaluronidase [48,69], phospholipase $A_{2}[48,69]$, proteolytic $[48,69]$, and vibriocidal [70] activities.

\section{Anthelmintic activities}

Kone et al. [25] evaluated the anthelmintic activities of ethanol stem bark extract of L. acida using the nematode Haemonchus contortus Rudolphi as the test species and ivermectin and fenbendazole, commercial anthelmintics as positive controls by determining the number of unhatched eggs and the number of larvae, the developmental stages of larvae, and their mobility. The extract exhibited larvicidal concentration $\left(\mathrm{LC}_{100}\right.$ ) value of $0.8 \mathrm{mg} / \mathrm{ml}$, while ivermectin and fenbendazole exhibited $\mathrm{LC}_{100}$ values of $0.001 \mathrm{mg} / \mathrm{ml}$ and $0.01 \mathrm{mg} / \mathrm{ml}$, 
respectively [25]. The anthelmintic activities exhibited by the species corroborate the traditional usage of the bark and leaves of $L$ acida against intestinal worms in Niger [40] and as ethnoveterinary medicine against intestinal parasites in Cameroon [20].

\section{Antidiarrheal activities}

Etuk et al. [37] evaluated the antidiarrheal activities of the aqueous bark extract of L. acida using the castor oil model of diarrhea induction in Wistar rats with diphenoxylate as a standard antidiarrheal agent. The oral administration of $200 \mathrm{mg} / \mathrm{kg}$ of the extracts exhibited inhibition against castor oil-induced diarrhea in rats [37]. These results show that L. acida extracts have potential in the management of gastrointestinal problems such as abdominal bloating, constipation, diarrhea, dysentery, and stomach ache $[24,25,27,28,34,36-41]$. Research by Stark et al. [71]

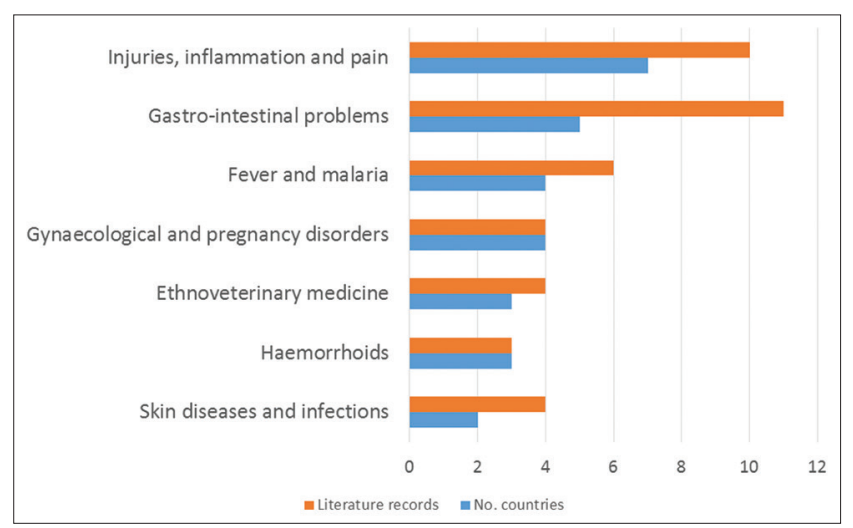

Fig. 1: Main medicinal uses of Lannea acida in West Africa

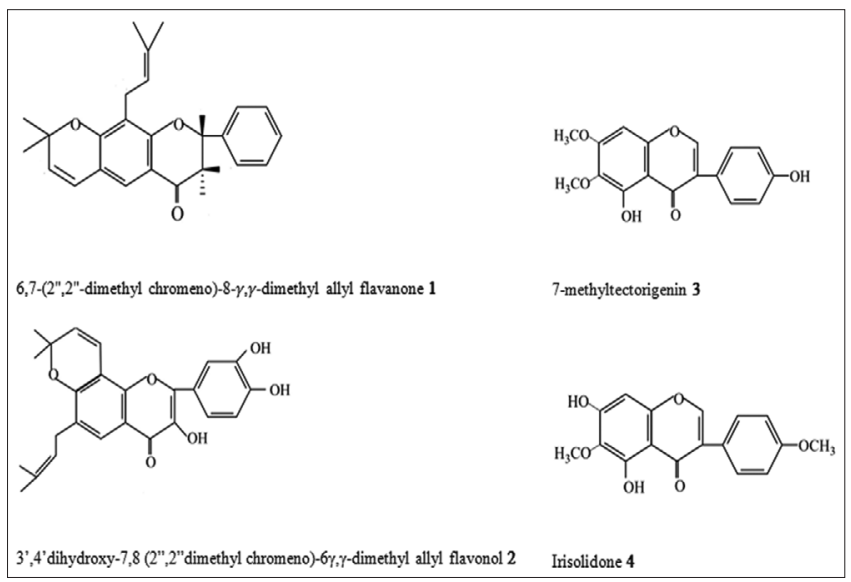

Fig. 2: Chemical structures of flavonoids identified from the bark and leaves of Lannea acid and Maroyi [72] showed that medicinal plants have potential in the treatment of gastrointestinal disorders and the pain that is associated with the disorders.

\section{Antibacterial activities}

Kone et al. [24] evaluated antibacterial activities of ethanol root extracts of L. acida against Escherichia coli, Pseudomonas aeruginosa, Staphylococcus aureus, Enterococcus faecalis, Streptococcus pyogenes, and Bacillus subtilis using agar diffusion and microdilution methods with gentamicin and tetracycline as positive controls. The extracts were active against $S$. aureus, E. faecalis, and $S$. pyogenes with minimum inhibitory concentration (MIC) values ranging from $23 \mu \mathrm{g} / \mathrm{ml}$ to $1500 \mu \mathrm{g} / \mathrm{ml}$ and half maximal inhibitory concentration $\left(\mathrm{IC}_{50}\right)$ values ranging from $94 \mu \mathrm{g} / \mathrm{ml}$ to $188 \mu \mathrm{g} / \mathrm{ml}$. The MIC values exhibited by the two controls ranged from $0.2 \mu \mathrm{g} / \mathrm{ml}$ to $>50 \mu \mathrm{g} / \mathrm{ml}$ and $\mathrm{IC}_{50}$ values ranged from $25 \mu \mathrm{g} / \mathrm{ml}$ to $50 \mu \mathrm{g} / \mathrm{ml}$ [24]. Ouattara et al. [67] evaluated antibacterial activities of ethanol bark extracts of L. acida against Bacillus subtilus, Enterobacter aerogenes, E. faecalis, Proteus mirabilis, $P$. aeruginosa, Salmonella enterica, Salmonella typhimurium, S. aureus, and Staphylococcus camorum using disc diffusion and broth microdilution methods with ciprofloxacin, erythromycin, and tetracycline as positive controls. The extracts exhibited activities against all tested pathogens except E. aerogenes with 11-17 mm zone of inhibition. The extracts were active against most pathogens except $S$. typhimurium with MIC values ranging from 7.8 to $125.0 \mu \mathrm{g} / \mathrm{mL}$ and minimum bactericidal concentration values ranging from 15.6 to $>500.0 \mu \mathrm{g} / \mathrm{mL}$ [67]. These antibacterial activities exhibited by the extracts of $L$. acida support the traditional usage of the species as remedy for bacterial pathogens causing diarrhea $[24,25,27,34,37,39,41]$, dysentery $[25,34,38,40]$, furuncle [28], gonorrhea [24], microbial infections on burns and wounds [3,22,23], skin infections [36], stomach ache $[24,28,36,38,39,40]$, and toothache $[13,26]$.

\section{Anti-inflammatory activities}

Owusu and Ofori-Amoah [64] evaluated anti-inflammatory activities of aqueous stem bark extract of $L$. acida using paw edema and writhing test assays in male Sprague Dawley rats. The extract at $30-300 \mathrm{mg} / \mathrm{kg}$ reduced prostaglandin E2-induced paw edema in both prophylactic and curative protocols. The extract also significantly inhibited acetic acidinduced abdominal writhing movement in imprint control region mice. In the prophylactic protocol, at $30 \mathrm{mg} / \mathrm{kg}$, the percentage total inhibitory effects of the extract were $68.4 \%$, while in the curative protocol, the percentage maximal inhibitory effects of the extract at $300 \mathrm{mg} / \mathrm{kg}$ were $67.1 \%$. The extracts inhibited prostaglandin E2-induced paw edema and acetic acid-induced writhing movements in animal models and, therefore, are potential remedies for inflammation and pain [64], corroborating the traditional usage of the species against rheumatism $[3,22,24]$, swellings [3,22,29], ulcers [27], and wounds [3,22,23].

\section{Antimycobacterial activities}

Ouattara et al. [34] evaluated antimycobacterial activities of ethanolwater bark extract of L. acida using the anti-Mycobacterium tuberculosis

Table 2: Nutritional composition of fruits and other plant parts of bark, leaves, and stem bark of Lannea acida

\begin{tabular}{lll}
\hline Caloric and nutritional composition & Values & Plant parts \\
\hline Alkaloids (mg equivalent berberine/g dry weight) & References \\
Total flavonoids (mg GAE/100 g lyophilized extract) & $31.6 \pm 5.6$ & Bark \\
Total phenolics (g GAE/100 g lyophilized extract) & $87-250$ & Bark \\
Energy value (kJ per 100 g) & $15.1-40.6$ & Bark and stem bark Leaves \\
Moisture (\% of dry weight) & 69.0 & Leaves \\
Fat (\% of dry weight) & 79.0 & Leaves \\
Protein (\% of dry weight) & 4.0 & Leaves \\
Carbohydrates (\% of dry weight) & 3.4 & Leaves \\
Fiber (\% of dry weight) & 14.0 & Leaves \\
Ash (\% of dry weight) & 2.2 & Leaves \\
Calcium (g/100 g) & 1.0 & Leaves \\
Phosphorus (mg/100 g) & 187.0 & Leaves \\
\hline
\end{tabular}

GAE: Gallic acid equivalent 
assay against $M$. tuberculosis $\mathrm{H} 37 \mathrm{Rv}$. The percentage of inhibition of M. tuberculosis proliferation was $77.6 \%$ and $36.8 \%$ at 1.2 and $0.6 \mathrm{mg} / \mathrm{mL}$, respectively [34]. These documented antimycobacterial activities of $L$. acida extracts which support the medicinal uses of the species in the treatment of respiratory system disorders including cough in Burkina Faso [34].

\section{Antioxidant activities}

Ouattara et al. [67] evaluated antioxidant activities of ethanol bark extracts of L. acida using the 2,2'-diphenyl-1-picrylhydrazyl (DPPH) free radical scavenging assay with gallic acid and quercetin as positive controls. The extract exhibited IC ${ }_{50}$ value of $345.7 \mu \mathrm{g} / \mathrm{mL}$, while the controls, gallic acid and quercetin exhibited much lower $\mathrm{IC}_{50}$ values of $0.6 \mu \mathrm{g} / \mathrm{mL}$ and $0.9 \mu \mathrm{g} / \mathrm{mL}$, respectively [67]. Onoshe et al. [65] evaluated the antioxidant activities of ethyl acetate stem bark extracts of L. acida using the DPPH free radical scavenging assay with ascorbic acid as control. The extract exhibited the highest percentage scavenging activity of $90 \%$ at a concentration of $20 \mathrm{mg} / \mathrm{mL}$ which was comparable to scavenging activity exhibited by ascorbic acid, although the scavenging activity of the control was relatively more pronounced than that of the extract at $2.5 \mathrm{mg} / \mathrm{mL}$, $5 \mathrm{mg} / \mathrm{mL}$, and $10 \mathrm{mg} / \mathrm{mL}$ [65]. The antioxidant activities exhibited by L. acida extracts are probably due to flavonoids and phenolics that have been identified from the species $[41,51,52,65,67]$, and flavonoids and phenolics are known to exhibit antioxidant properties [73-81].

\section{Estrogenic activities}

Oumarou et al. [41] evaluated the estrogenic activities of bark ethanolic extracts of L. acida using a 3-day uterotrophic assay and a 12-week oral treatment in ovariectomized adult female Wistar rats. To evaluate estrogenic-like effects of L. acida extracts, a simple and sensitive E-screen cell proliferation assay was performed with MCF-7 cells. The 3-day oral administration of bark extracts induced an increase in uterine wet weight, uterine water content, uterine total protein and glycogen levels, uterine and vaginal epithelial heights, and mammary glands differentiation. At $200 \mathrm{mg} / \mathrm{kg}$, a long-term treatment with the extract prevented body weight gain and loss of bone mass and/or density induced by ovariectomy [41]. L. acida extract improved bone microarchitecture and could restore normal bone mineralization by increasing the inorganic phosphorus and calcium level in bone. The L. acida ethanol extract induced a significant increase of MCF-7 cells yield at concentrations of $10 \mu \mathrm{g} / \mathrm{mL}, 100 \mu \mathrm{g} / \mathrm{mL}$, and $200 \mu \mathrm{g} / \mathrm{mL}$ as compared to DMSO control [41]. Taken altogether, this finding provides the evidence that $L$. acida is a potential alternative for the prevention of postmenopausal osteoporosis which occurs as a consequence of estrogen decline at menopause [41].

\section{Fertility activities}

Ahmed et al. [68] evaluated the effect of methanolic stem bark extract of $L$. acida on sperm count, sperm motility, sperm morphology, serum testosterone, and histology of the testes on male Wistar rats. Results of this study showed that the administration of the stem bark extract of L. acida increased sperm count, morphology, motility, and serum testosterone levels in Wistar rats [68].

\section{Hyaluronidase activities}

Molander et al. [48] evaluated the hyaluronidase activities of aqueous and ethanol cortex extracts of L. acida using the hyaluronidase assay with aristolochic acid as a positive control and Bitis arietans and Naja nigricollis as enzyme sources. The aqueous and ethanol extracts exhibited inhibition of $64 \%$ and $111 \%$, respectively, where B. arietans was used as an enzyme source and $101 \%$ and $136 \%$ where N. nigricollis was used. Both the extracts exhibited $\mathrm{IC}_{50}$ values of $0.1 \mathrm{mg} / \mathrm{ml}$. The ethanol extract exhibited an $\mathrm{IC}_{50}$ value of 0.08 after removal of polyphenols [48]. Molander et al. [69] also evaluated aqueous and ethanol cortex extracts of L. acida in an ex vivo air-liquid interface model, and a wound healing scratch assay as well as for their ability to permeate the skin barrier and inhibit venom-induced cell death. The extracts were not able to lower the cell toxicity of the venom and showed no effect against cell death and tissue damage [69].

\section{Phospholipase $\mathrm{A}_{2}$ activities}

Molander et al. [48] evaluated the phospholipase $A_{2}$ activities of aqueous and ethanol cortex extracts of $L$. acida using the phospholipase $\mathrm{A}_{2}$ activity assay with ethylenediaminetetraacetic acid (EDTA) as a positive control and B. arietans as an enzyme source. The aqueous and ethanol extracts exhibited inhibition of $137 \%$ and $122 \%$, respectively, and $\mathrm{IC}_{50}$ values of $0.2 \mathrm{mg} / \mathrm{ml}$ and $0.1 \mathrm{mg} / \mathrm{ml}$. The ethanol extract exhibited an $\mathrm{IC}_{50}$ value of 0.2 after the removal of polyphenols [48]. Molander et al. [69] also evaluated aqueous and ethanol cortex extracts of L. acida in an ex vivo air-liquid interface model and a wound healing scratch assay as well as for their ability to permeate the skin barrier and inhibit venom-induced cell death. The extracts were not able to lower the cell toxicity of the venom and showed no effect against cell death and tissue damage [69].

\section{Proteolytic activities}

Molander et al. [48] evaluated the protease activities of aqueous and ethanol cortex extracts of $L$. acida using casein as substrate according to the method of Satake et al. [82] adjusted to microtiter plates with 4-(2-aminoethyl)benzenesulfonyl fluoride and EDTA as positive controls and B. arietans as an enzyme source. The aqueous and ethanol extracts exhibited inhibition of $102 \%$ and $86 \%$, respectively, while aqueous extract exhibited $\mathrm{IC}_{50}$ value of $0.2 \mathrm{mg} / \mathrm{ml}$ [48]. Molander et al. [69] also evaluated aqueous and ethanol cortex extracts of L. acida in an ex vivo air-liquid interface model and a wound healing scratch assay as well as for their ability to permeate the skin barrier and inhibit venom-induced cell death. The extracts were not able to lower the cell toxicity of the venom and showed no effect against cell death and tissue damage [69].

\section{Vibriocidal activities}

Akinsinde and Olukoya [70] evaluated vibriocidal activities of aqueous and ethanol stem extracts of L. acida against Vibrio cholerae using agar diffusion method with streptomycin as control. The extracts showed moderate activities with a zone of inhibition ranging from 5 to $15 \mathrm{~mm}$ [70]. These antibacterial activities exhibited by extracts of $L$. acida support the traditional usage of the plant as a remedy for diarrhea in Cameroon Burkina Faso [34,39], Cameroon [41], Côte d'Ivoire [24,25], and Nigeria [27,37].

\section{CONCLUSION}

L. acida is an important herbal medicine in West Africa, and there are still some research gaps in the phytochemical and pharmacological analyses of the crude extracts of the species as well as compounds isolated from the species. There is a need to correlate the medicinal uses of the species with the chemical compounds and pharmacological properties of the compounds and extracts of the species. Detailed research on pharmacokinetics, in vivo, and clinical research involving compounds isolated from L. acida and extracts of the species are required. Future research should also focus on the toxicological properties of the compounds isolated from the species as well as its crude extracts. Since L. acida is used in combination with other plant species in various herbal concoctions, it is important to evaluate the synergistic effects of the different extracts and their ability to enhance the efficiency of the additive mixtures. Detailed phytochemical, pharmacological, and toxicological studies will enable researchers to evaluate the therapeutical importance of the species in tropical Africa $[83,84]$.

\section{AUTHORS' CONTRIBUTIONS}

I declare that this work was done by the author named in this article.

\section{CONFLICTS OF INTEREST}

No conflicts of interest are associated with this work.

\section{ACKNOWLEDGMENTS}

The author would like to express his gratitude to the National Research Foundation (NRF), South Africa, and Govan Mbeki Research and 
Development Centre (GMRDC), University of Fort Hare, for financial support to conduct this study.

\section{REFERENCES}

1. Palmer E, Pitman N. Trees of Southern Africa Covering all Known Indigenous Species in the REPUBLIC of South Africa, South-West Africa, Botswana, Lesotho and Swaziland. Cape Town: Balkema; 1972.

2. Schmidt E, Lotter M, McCleland W. Trees and shrubs of Mpumalanga and Kruger National Park. Johannesburg: Jacana Media; 2002.

3. Oliver D. Flora of Tropical Africa: Ranunculaceae to Connaraceae. Kent: L. Reeve \& Co.; 1968

4. Hou D. Anacardiaceae. In: Van Steenis CG, editor. Flora Malesiana, Voli. Leiden: Sijthoff and Noordhoff; 1978. p. 395-548.

5. Wannan BS. Analysis of generic relationships in Anacardiaceae. Blumea 2006;51:165-95.

6. Pell SK, Mitchell JD, Miller AJ, Lobova TA. Anacardiaceae. In: Kubitzki K, editor. The Families and Genera of Vascular Plants: Flowering Plants Eucodicots Sapindales, Cucurbitales and Myrtaceae. Vol. 10. London: Springer; 2011. p. 7-50.

7. Sofowora A. Medicinal Plants and Traditional Medicine in Africa. Chichester: Wiley; 1982.

8. Oliver-Bever B. Medicinal Plants of Tropical West Africa. Cambridge: Cambridge University Press; 1986.

9. Steentoft M. Flowering Plants in West Africa. Cambridge: Cambridge University Press; 1988

10. Iwu M. Handbook of African Medicinal Plants. Boca Raton: CRC Press; 2014.

11. Neuwinger HD. African Traditional Medicine: A Dictionary of Plant use and Applications. Stuttagart: Medpharm Scientific Publishers; 2000.

12. Arbonnier M. Trees, Shrubs and Lianas of West African Dry Zones. Montpellier: CIRAD, Margraf Publishers GMBH MNHN; 2004.

13. Burkill HM. The Useful Plants of West Tropical Africa. London: Royal Botanic Gardens, Kew; 1995.

14. National Research Council. Lost crops of Africa. Fruits. Vol. 3. Washington, DC: The National Academies Press; 2008

15. Marquet A, Jansen PC. Lannea microcarpa Engl. and K. Krause. In: Jansen PC, Cardon D, editors. Plant Resources of Tropical Africa 3: Dyes and Tannins. Wageningen: PROTA Foundation; 2005. p. 102-4.

16. Cook FE. Economic Botany Data Collection Standard. Prepared for the Interantional Working Group on Taxonomic Databases for Plant Sciences (TDWG). London: Royal Botanic Gardens, Kew; 1995.

17. Gruca M, Cámara-Leret R, Macía MJ, Balslev H. New categories for traditional medicine in the Economic botany data collection standard. J Ethnopharmacol 2014;155:1388-92.

18. Soladoye MO, Amusa NA, Raji-Esan SO, Chukwuma EC, Taiwo AA. Ethnobotanical survey of anti-cancer plants in Ogun State, Nigeria. Ann Biol Res 2010;1:261-73.

19. Asase A, Oteng-Yeboah AA, Odamtten GT, Simmonds MS. Ethnobotanical study of some Ghanaian anti-malarial plants. J Ethnopharmacol 2005;99:273-9.

20. Djoueche CM, Azebaze AB, Dongmo AB. Investigation of plants used for the ethnoveterinary control of gastrointestinal parasites in Bénoué region, Cameroon. Tropicultura 2011;29:205-11.

21. Kpodékon TM, Ogni CA, Dassou H, Dougnon TJ, Boko C, Koutinhouin GB, et al. Dominant viral pathologies in the extensive and semi-intensive animal breeding and their treatment mode in ethno veterinary medicine in Benin. Vet World 2015;8:1424-34.

22. Ellenberg H, Galat-Luong A, von Maydell HJ, Mühlenberg M, Panzer KF, Schmidt-Lorenz R, et al. Pirrang: Ecological Investigation in Forest Island in the Gambia. Hamburg: Stiftung Walderhaltung in Afrika und Bundesanstaltfür Forst-und Holzwirtschaft, Traute Warnke Verlag, Reinbek b; 1998 .

23. Diallo D, Sogn C, Samaké FB, Paulsen BS, Michaelsen TE, Keita A. Wound healing plants in Mali, the Bamako region: An ethnobotanical survey and complement fixation of water extracts from selected plants. Pharmaceut Biol 2002;40:117-28.

24. Koné WM, Atindehou KK, Terreaux C, Hostettmann K, Traoré D, Dosso M. Traditional medicine in north Côted'Ivoire: Screening of 50 medicinal plants for antibacterial activity. J Ethnopharmacol 2004;93:43-9.

25. Koné WM, Atindehou KK, Dossahoua T, Betschart B. Anthelmintic activity of medicinal plants used in northern Côte d'Ivoire against intestinal helminthiasis. Pharmaceut Biol 2005;43:72-8.

26. Tapsoba H, Deschamps JP. Use of medicinal plants for the treatment of oral diseases in Burkina Faso. J Ethnopharmacol 2006;104:68-78.

27. Oluranti AC, Michael UO, Ugwah-Oguejiofor JC, Ayembe NA. Ethno botanical studies of medicinal plants used in the management of peptic ulcer disease in Sokoto State, North Western Nigeria. Int Res J Pharm Pharmacol 2012;2:225-30.

28. Yaoitcha AS, Houehanou TD, Fandohan AB, Houinato MR. Prioritization of useful medicinal tree species for conservation in WariMaroforest reserve in Benin: A multivariate analysis approach. For Policy Econ 2015;61:135-46.

29. Dossou-Yovo HO, Vodouhe FG, Sinsin B. Assessment of the medicinal uses of plant species found on termitaria in the Pendjari biosphere reserve in Benin. J Med Plants Res 2014;8:368-77.

30. Amusa TO, Jimoh SO, Aridanzi P, Haruna M. Ethnobotany and Conservation of plant resources of Kainji Lake national Park, Nigeria. Ethnobot Res Appl 2010;8:181-94.

31. Sowemimo A, van de Venter M, Baatjies L, Koekemoer T. Cytotoxic activity of selected Nigerian plants. Afr J Tradit Complement Altern Med 2009;6:526-8

32. Kinda PT, Zerbo P, Guenné S, Compaoré M, Ciobica A, Kiendrebeogo M, et al. Medicinal plants used for neuropsychiatric disorders treatment in the Hauts Bassins region of Burkina Faso. Medicines (Basel) 2017:4:32.

33. Ziblim IA, Timothy KA, Deo-Anyi EJ. Exploitation and use of medicinal plants, Northern region, Ghana. J Med Plants Res 2013;7:1984-93.

34. Ouattara L, Koudou J, Karou DS, Giacò L, Capelli G, Simpore J, et al. In vitro anti Mycobacterium tuberculosis $\mathrm{H} 37 \mathrm{Rv}$ activity of Lannea acida A. Rich from Burkina Faso. Pak J Biol Sci 2011;14:47-52.

35. Diallo A, Traore MS, Keita SM, Balde MA, Keita A, Camara M, et al. Management of diabetes in Guinean traditional medicine: An ethnobotanical investigation in the coastal lowlands. J Ethnopharmacol 2012;144:353-61.

36. Muhammad S, Amusa NA. The important food crops and medicinal plants of North-Western Nigeria. Res J Agr Biol Sci 2005;1:254-60.

37. Etuk EU, Ugwah MO, Ajagbonna OP, Onyeyili PA. Ethnobotanical survey and preliminary evaluation of medicinal plants with antidiarrhoea properties in Sokoto State, Nigeria. J Med Plants Res 2009;3:763-6.

38. Obata OO, Aigbokhan EI. Ethnobotanical practices among the people of Okaakoko, Nigeria. Pl Arch 2012;12:627-38.

39. Sore H, Hilou A, Sombie P, Compaore M, Millogo J, Nacoulma OG. Dyeing and medicinal plants used in the area of Mouhoun in Burkina Faso. Univ J Env Res Technol 2012;2:110-8.

40. Manzo LM, Moussa I, Ikhri K. Ethnobotanical survey: A comprehensive review of medicinal plants used against gastrointestinal disorders in Niger, West Africa. Jundishapur J Nat Pharm Prod 2017;12:e65730.

41. Oumarou MR, Zingue S, Bakam BY, Ateba SB, Foyet SH, Mbakop FT, et al. Lannea acida A. Rich. (Anacardiaceae) ethanol extract exhibits estrogenic effects and prevents bone loss in an ovariectomizedrat model of osteoporosis. Evid Based Complem Altern Med 2017;2017:Article ID: 7829059

42. Nadembega P, Boussim JI, Nikiema JB, Poli F, Antognoni F. Medicinal plants in Baskoure, Kourittenga province, Burkina Faso: An ethnobotanical study. J Ethnopharmacol 2011;133:378-95.

43. Allabi AC, Busia K, Ekanmian V, Bakiono F. The use of medicinal plants in self-care in the Agonlin region of Benin. J Ethnopharmacol 2011;133:234-3.

44. Buochuama A, Akhabue EF. Ethnomedicinal and phytochemical evaluation of tree species among some local folks of northern Nigeria. World Sci News 2018;99:60-70.

45. Kankara SS, Ibrahim MH, Mustafa M, Go R. Ethnobotanical survey of medicinal plants used for traditional maternal healthcare in Katsina state, Nigeria. S Afr J Bot 2015;97:165-75.

46. Adelanwa MA, Haruna HB. Survey of some plants found in Guraralocal government area of Niger State, Nigeria. Int J Appl Biol Res 2013;5:43-54

47. Ajibesin KK. Ethnobotanical survey of plants used for skin diseases and related ailments in AkwaIbom State, Nigeria. Ethnobot Res Appl 2012;10:463-522.

48. Molander M, Nielsen L, Søgaard S, Staerk D, Rønsted N, Diallo D, et al. Hyaluronidase, phospholipase A2 and protease inhibitory activity of plants used in traditional treatment of snakebite-induced tissue necrosis in Mali, DR Congo and South Africa. J Ethnopharmacol 2014; $157: 171-80$.

49. Tamboura H, Kaboré H, Yaméogo SM. Ethnoveterinary medicine and indigenous pharmacopeia in central region of Burkina Faso: Case of Passore Province. Biotechnol Agron Soc Environ 1998;2:181-91.

50. China TF, Olounlade PA, Salifou S. Ethnobotanical study of endogenous methods used for the treatment of diseases of Sombacattle breed in Northern Benin. J Drug Delivery Therapeut 2014;4:91-9.

51. Sultana S, Ilyas M. A flavanone from Lannea acida. Phytochemistry 
1986;25:963-4.

52. Muhaisen HM. Chemical constituents from the bark of Lannea acida rich (Anacardiaceae). Scholars Res Libr 2013;5:88-96.

53. Bae EA, Han MJ, Kim DH. In vitro anti-helicobacter pylori activity of irisolidone isolated from the flowers and rhizomes of Pueraria thunbergiana. Planta Med 2001;67:161-3.

54. Yamaki K, Kim DH, Ryu N, Kim YP, Shin KH, Ohuchi K, et al. Effects of naturally occurring isoflavones on prostaglandin E2 production. Planta Med 2002;68:97-100.

55. Han YO, Han MJ, Park SH, Kim DH. Protective effects of kakkalide from Flospuerariae on ethanol-induced lethality and hepatic injury are dependent on its biotransformation by human intestinal microflora. J Pharmacol Sci 2003;93:331-6.

56. Lee HU, Bae EA, Kim DH. Hepatoprotective effects of irisolidone on tert-butyl hyperoxide-induced liver injury. Biol Pharm Bull 2005;28:531-3.

57. Wollenweber E, Stevens JF, Klimo K, Knauft J, Frank N, Gerhäuser C, et al. Cancer chemopreventive in vitro activities of isoflavones isolated from iris Germanica. Planta Med 2003;69:15-20.

58. Shin JE, Bae EA, Lee YC, Ma JY, Kim DH. Estrogenic effect of main components kakkalide and tectoridin of puerariaeflos and their metabolites. Biol Pharm Bull 2006;29:1202-6.

59. Kim SY, Kim DH, Hyun JW, Henson JW, Kim HS. Irisolidone, an isoflavone metabolite, represses JC virus gene expression via inhibition of sp1 binding in human glial cells. Biochem Biophys Res Commun 2006;344:3-8

60. Park JS, Woo MS, Kim DH, Hyun JW, Kim WK, Lee JC, et al. Anti-inflammatory mechanisms of isoflavone metabolites in lipopolysaccharide-stimulated microglial cells. J Pharmacol Exp Ther 2007;320:1237-45

61. Min SW, Park YJ, Kim DH. Kakkalide and its metabolite irisolidone ameliorate carrageenan-induced inflammation in mice by inhibiting NF- $\kappa$ B pathway. Inflammation 2011;34:344-51.

62. Kang KA, Zhang R, Piao MJ, Ko DO, Wang ZH, Kim BJ, et al. Protective effect of irisolidone, a metabolite of kakkalide, against hydrogen peroxide induced cell damage via antioxidant effect. Bioorg Med Chem 2008;16:1133-41.

63. Manzo LM, Moussa I, Ikhiri K. Phytochemical screening of selected medicinal plants used against diarrhea in Niger, West Africa. Int J Herbal Med 2017;5:32-8

64. Owusu G, Ofori-Amoah J. Anti-inflammatory and analgesic effects of an aqueous extract of Lannea acida stem bark. Br J Pharmaceut Res 2017; $16: 1-8$

65. Onoshe S, Azubuike MM, Hitler L, Oghenekevwe IE, Mary MA, Amos PI. Free radical scavenging activity and preliminary phytochemical screening of ethylacetate fraction of stem bark of Lannea acida (A. Rich). J Nat Prod Resour 2018;4:182-4.

66. Leung WT, Busson F, Jardin C. Food Composition Tables for use in Africa. Rome: Food and Agriculture Organization (FAO) of the United Nations; 1968.

67. Ouattara L, Koudou J, Zongo C, Barro N, Sawadogo A, Bassole IH, et al. Antioxidant and antibacterial activities of three species of Lannea from Burkina Faso. J Appl Sci 2011;11:157-62.

68. Ahmed MK, Mabrouk MA, Anuka JA, Attahir A, Tanko Y, Wawata AU, et al. Studies of the effect of methanolic stem bark extract of Lannea acida on fertility and testosterone in male wistar rats. J Med Sci 2010;7:6-7.

69. Molander M, Staerk D, Nielsen HM, Brandner JM, Diallo D, Chifundera KZ, et al. Investigation of skin permeation, ex vivo inhibition of venom-induced tissue destruction, and wound healing of African plants used against snakebites. J Ethnopharmacol 2015;165:1-8.

70. Akinsinde KA, Olukoya DK. Vibriocidal activities of some local herbs. J Diarrhoeal Dis Res 1995;13:127-9.

71. Stark TD, Mtui DJ, Balemba OB. Ethnopharmacological survey of plants used in the traditional treatment of gastrointestinal pain, inflammation and diarrhea in Africa: Future perspectives for integration into modern medicine. Animals (Basel) 2013;3:158-227.

72. Maroyi A. Treatment of diarrhoea using traditional medicines: Contemporary research in South Africa and Zimbabwe. Afr J Tradit Complement Altern Med 2016;13:5-10.

73. Rice-Evans CA, Miller NJ, Paganga G. Structure-antioxidant activity relationships of flavonoids and phenolic acids. Free Radic Biol Med 1996;20:933-56.

74. Pietta PG. Flavonoids as antioxidants. J Nat Prod 2000;63:1035-42.

75. Heim KE, Tagliaferro AR, Bobilya DJ. Flavonoid antioxidants: Chemistry, metabolism and structure-activity relationships. J Nutr Biochem 2002;13:572-84.

76. Khlebnikov AI, Schepetkin IA, Domina NG, Kirpotina LN, Quinn MT. Improved quantitative structure-activity relationship models to predict antioxidant activity of flavonoids in chemical, enzymatic, and cellular systems. Bioorg Med Chem 2007;15:1749-70.

77. Kancheva VD. Phenolic antioxidants-radical-scavenging and chainbreaking activity: A comparative study. Eur J Lipid Sci Technol 2009;111:1072-89.

78. Procházková $\mathrm{D}$, Boušová $\mathrm{I}$, Wilhelmová N. Antioxidant and prooxidant properties of flavonoids. Fitoterapia 2011;82:513-23.

79. Palacios I, Lozano M, Moro C, D’Arrigo M, Rostagno MA, Martínez JA, et al. Antioxidant properties of phenolic compounds occuring in edible mushrooms. Food Chem 2011;128:674-8

80. Zhang H, Tsao R. Dietary polyphenols, oxidative stress and antioxidant and anti-inflammatory effects. Cur Opinion Food Sci 2016;8:33-42.

81. Severini C, Derossi A, Fiore AG. Ultrasound-assisted extraction to improve the recovery of phenols and antioxidants from spent espresso coffee ground: A study by response surface methodology and desirability approach. Eur Food Res Technol 2017;243:835.

82. Satake M, Murata Y, Suzuki T. Studies on snake venom. XIII. Chromatographic separation and properties of three proteinases from Agkistrodon halys blomhoffii venom. J Biochem 1963;53:438-47.

83. Athipornchai A. A review on Tabernaemontana spp.: Multipotential medicinal plant. Asian J Pharm Clin Res 2018;11:45-53

84. Maroyi A. Dicoma anomala sond.: A review of its botany, ethnomedicine, phytochemistry and pharmacology. Asian J Pharm Clinl Res 2018;11:70-7. 